\title{
Bacterial Resistance in Ophthalmology - Resistance Profile, Influencing Factors and Prevention Methods. A Review
}

\author{
Matei POPA-CHERECHEANU ${ }^{1,3}$, Alina POPA-CHERECHEANU ${ }^{1,2}$, Dan George DELEANU², \\ Mihai Aurelian GHITA ${ }^{1,2,4}$
}

\begin{abstract}
Ocular infections vary greatly in severity. Studies have tried to identify certain patterns related to the ocular microbiome in the studied populations in order to identify risk populations, new treatments and prophylaxis guidelines. However, it is critical to determine which antibiotics should be used in various situations and where alternatives to antibiotics are appropriate. Results of many studies show that high levels of antibiotic resistance in ophthalmology and multidrug resistance continue to be a reality and a challenge today.

lodine-povidone and chlorhexidine are two major antiseptics used in ophthalmology. It is hoped that future reports show good results without the use of antibiotics will encourage ophthalmologists to limit the use of topical antibiotics, reducing the rate of antimicrobial resistance.
\end{abstract}

Keywords: bacterial resistance, ocular drug resistance, conjunctival flora, ocular microbiome.

\section{Rezumat}

Infecțiile oculare pot varia mult ca severitate. S-a încercat în acest sens identificarea pacienților cu risc de a face infecții severe postoperatorii, precum și metode de profilaxie și tratament ale acestora. Este, de asemenea, important de stabilit dacă în toate situațiile este necesară administrarea antibioticelor sau se poate recurge la administrarea de antiseptice, povidon-iodina și clorhexidina fiind alternative eficiente folosite în oftalmologie.

Sunt, de asemenea, de deprins anumite ritualuri, bazate pe dovezi, în care să se renunțe la folosirea nejustificată a antibioticelor topice și înlocuirea (atunci când este cazul) cu antiseptice topice.

Cuvinte cheie: rezistență bacteriană, rezistență la medicamentele pentru uz ocular, floră conjunctivală, microbiom ocular.

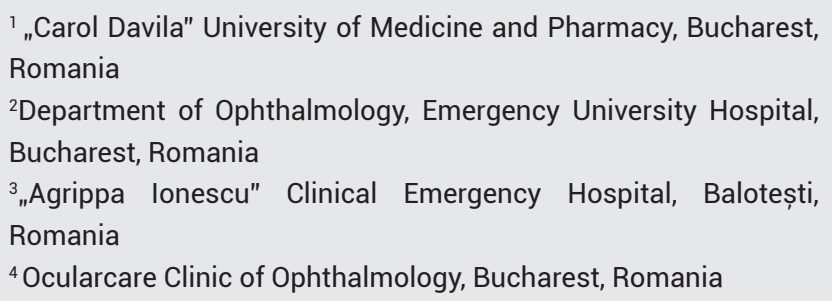

\section{Corresponding author.}

Dan George DELEANU, Department of Ophthalmology,

Emergency University Hospital, Bucharest, Romania

E-mail: dangeorge_deleanu@yahoo.com 


\section{INTRODUCTION}

Ocular infections vary greatly in severity. Bacterial conjunctivitis is probably the most common eye infection, but it is also self-limiting and does not endanger the patient's sight ${ }^{1}$. At the other end of the spectrum of severity is endophthalmitis, a quite rare but still extremely serious complication of eye surgery (mainly after cataract surgery), eye trauma or intravitreal injections ${ }^{2}$. Growing resistance of microorganisms to antibiotics questions the effectiveness of treatment in eye infections ${ }^{3}$.

The eye is well protected from environmental microbes. Penetrating injuries, whether accidental, surgical or associated with intraocular injections, can facilitate the occurrence of eye infections with ocular germs ${ }^{4}$. Although endophthalmitis is considered a very rare complication, with an estimated incidence of approximately $0.03-0.2 \%$ after cataract surgery and $0.02-0.2 \%$ after a single intravitreal injection, the large number of such procedures results in thousands of cases of endophthalmitis annually ${ }^{5}$. In addition, the poor outcome of acute endophthalmitis causes vision loss in a significant number of cases.

The devastating effects of endophthalmitis have led many ophthalmologists to prophylactically use topical perioperative antimicrobial therapy. In a 2001 study by the American Society of Cataract and Refractive Surgery on the use of antibiotics reported that $96 \%$ of the 1300 surveyed surgeons used topical antibiotics perioperatively. A more recent study (2014) showed that $90 \%$ of cataract surgens use antibiotics perioperatively 6,7 . The choice of antibiotic used depends on a multitude of factors, the major criteria included: the broad spectrum of action, the remaining time on the conjunctival surface, the costs and the resistance profile of the germs involved ${ }^{8,9}$.

\section{OCULAR INFECTIONS}

Using conventional culture media - chocolate agar or blood agar, broth culture $-75-82 \%$ of conjunctival cultures proved to be positive for at least one microorganism ${ }^{5}$.

Some of the most common bacteria found on the surface of the eye are coagulase-negative staphylococci (CoNS). They are considered commensal bacteria, colonizing the mucosa and the margins of the eyelids 4,11,12, Staphylococcus epidermidis being the predominant species $^{11}$. Since 1954 extensive studies conducted all over the world (Japan, Korea, USA, Finland, Uganda) have proven this ${ }^{4,11,13}$, and even in the rural populations of Sierra Leone ${ }^{14,15}$.

Staphylococcus aureus, Propionibacterium, Pseudomonas aeruginosa and Haemophilus inlfuenzae ${ }^{4,11,13,16-}$ ${ }^{20}$ are also common microorganisms of the ocular flora. Only recently studies used molecular techniques to determine the ocular microbiome ${ }^{8,11,13}$. In a study that compared conventional culture techniques and 16S RNA sequencing techniques and molecular techniques, a much wider range of microbes was identified using the second method, Rhodococcus sp., Klebsiella sp., Propionibacterium sp. and Erwinia sp. being also isolated ${ }^{21}$.

Studies have tried to identify certain patterns related to the ocular microbioma in the studied populations in order to identify risk populations, new treatments and prophylaxis guidelines.

A high prevalence of methicillin-resistant Staphylococcus aureus (MRSA) was observed in health care workers ${ }^{11}$. However, a study that investigated MRSA colonization showed that being employed in the health field or family member of a health care employee does not put an additional risk of being colonized by MRSA. This conclusion was supported by another study as well ${ }^{22}$.

Other studies reported that older patients, mainly over 80, are more likely to carry MRSA or methicillin-resistant CoNS. Methicillin resistance was reported in percentages of $29.5 \%$ (between $50-59$ years), $33.3 \%$ (60-69 years), 34\% (70-79 years), 48.3\% (80-89 years) and $50 \%$, respectively (90-99 years) ${ }^{23}$. Similar percentages of methicillin resistance were reported in another study in patients over 60 years ${ }^{18}$, but in another study from 2015 which evaluated 183 eyes preoperatively this correlation was not statistically significant $(P=0.06)^{13}$.

Two prospective studies in Japan have both shown that bacterial isolation rates are significantly lower in those who use eye drops. In a study that evaluated 579 eyes, patients who did not use eye drops had $46.7 \%$ ( $n=304$ ) of cultures positive compared to $30.9 \%$ $(\mathrm{n}=275)$ in users. Similar percentages were reported in patients with dry eye syndrome: $19.8 \%(\mathrm{n}=96)$, compared to $43.1 \%$ in those who did not use eye drops $(\mathrm{n}=483)^{23}$. A second study reported isolation rates of $40.3 \%$ ( $n=119, P<0.001)$ in patients using glaucoma eye drops, compared to $67.8 \%(\mathrm{n}=8, \mathrm{P}<0.05)$ in the control group ${ }^{23}$. The authors of these two studies hy- 
pothesized that this is the washout effect following the administration of the drops ${ }^{19}$.

There is contradictory data about the influence of diabetes on the ocular flora. Some studies did not find any significant difference in the rate of bacterial detection in relation to diabetic status, glycosylated hemoglobin, diabetic retinopathy or glycosuria ${ }^{13,19}$, but one of them reported a higher percentage of methicillin resistance in diabetic patients and a higher percentage, statistically significant $(\mathrm{P}=0.018)$ of gram-negative microorganisms in diabetics ${ }^{13}$. Moreover, in another study on the ocular bacterial flora in diabetic patients with both normal and modified levels of glycosylated hemoglobin $(\mathrm{HbA1c})$ respectively, no difference was found between the two groups ${ }^{24}$. In contrast, a 2010 study in US found diabetic patients less likely to be colonized by methicillin-resistant microbes $(\mathrm{P}=0.02)^{25}$.

Another factor suspected to influence the ocular flora is the geographical location ${ }^{18}$. The differences be- tween the ocular microbes and their resistance profile and the geographical region have been described since 1954, when in two London hospitals the results of the conjunctival cultures were different ${ }^{26}$. The results were supported by a study on 4432 patients who underwent cataract surgery between 1994 and 1996 in Madrid, which showed significant differences in the germs of the ocular surface, correlated with climate changes in seasons ${ }^{14}$. The authors found that in the hot and humid months - April, May and June - the rate of bacterial isolation increased. Such a seasonal effect was also observed for S. pneumoniae - the isolation increasing in March, November and December, and for Haemophilus $s p$. - in January and April ${ }^{27}$.

Other factors that have been correlated with changes in the composition of the surface ocular flora are alcoholism (with significantly higher incidence of $S$. aureus in those with chronic alcoholism compared to the rest of the population) ${ }^{27}$, Behçet's disease (signif-

\begin{tabular}{|c|c|c|c|c|}
\hline & Influencing factor & Relation & $\begin{array}{l}\text { Studies supporting } \\
\text { the hypothesis }\end{array}$ & $\begin{array}{l}\text { Studies which found no } \\
\text { correlation }\end{array}$ \\
\hline $\begin{array}{l}\text { Incidence of MRSA } \\
\text { colonization }\end{array}$ & 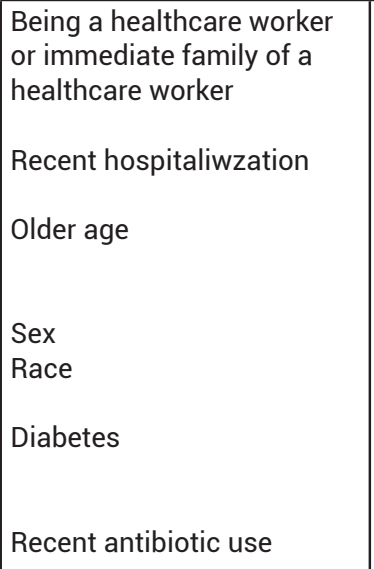 & $\begin{array}{l}\text { 个likelihood of MRSA colonization } \\
\text { 个likelihood of MRSA colonization } \\
\text { 个likelihood of MRSA colonization } \\
\downarrow \text { likelihood of MRSA colonization } \\
\text { 个likelihood of MRSA colonization } \\
\text { 个likelihood of MRSA colonization }\end{array}$ & $\begin{array}{l}\text { Olson et al. } 2010 \\
\text { Suto et al. } 2012 \\
\text { Olson et al. } 2010 \\
\text { Suto et al. } 2012 \\
\text { Hsu et al. } 2015\end{array}$ & $\begin{array}{l}\text { Olson et al. } 2010 \\
\text { Hsu et al. } 2015 \\
\text { Olson et al. } 2010 \\
\text { Hsu et al. } 2015 \\
\text { Hsu et al. } 2015 \\
\text { Hsu et al. } 2015\end{array}$ \\
\hline $\begin{array}{l}\text { Incidence of S. aureus } \\
\text { colonisation }\end{array}$ & $\begin{array}{l}\text { Alcoholism } \\
\text { Behçet's disease }\end{array}$ & $\begin{array}{l}\text { 个likelihood of } S \text {. aureus coloni- } \\
\text { sation } \\
\text { 个likelihood of S. aureus coloni- } \\
\text { sation }\end{array}$ & $\begin{array}{l}\text { Gündüz et al. } 2015 \\
\text { Gündüz et al. } 2008\end{array}$ & \\
\hline Culture-positive rate & $\begin{array}{l}\text { Regular use of eye drops } \\
\text { Diabetes } \\
\text { Hiperlipidemie } \\
\text { AIDS, immunosupresion } \\
\text { Pregnancy and reproductive } \\
\text { status }\end{array}$ & $\begin{array}{l}\uparrow c u l t u r e-p o s i t i v e ~ r a t e \\
\downarrow \text { culture-positive rate }\end{array}$ & $\begin{array}{l}\text { Suto et al. } 2012 \\
\text { Honda et al. } 2011 \\
\text { Nahar et al. } 2014 \\
\text { Suto et al. } 2012\end{array}$ & $\begin{array}{l}\text { Suto et al. } 2012 \\
\text { Adam et al. } 2015 \\
\text { Gritz et al. } 1997 \\
\text { Balikoglu et al. } 2012\end{array}$ \\
\hline
\end{tabular}

Table 1. Microbial flora and positive culture results in studies from different parts of the world. (adapted from Grzybowski et al. Microbial flora and resistance in ophthalmology: a review ${ }^{33}$ ) 
icantly higher percentages of colonization with $S$. aureus, Moraxella sp. and Streptococcus sp.) ${ }^{28}$ or hyperlipidemia (lower bacterial detection rates, possibly due to changes in fluid in the nasolacrimal duct) ${ }^{29}$.

Factors that have been investigated but not have been found to have any influence on the microbial flora include AIDS and immunosuppression ${ }^{13}$, pregnancy and reproductive status (women of reproductive age vs. postmenopause) ${ }^{30}$ and recent hospitalization (Table 1 ).

A trial on laboratory mice suggests that the ocular flora is useful for the development of an adequate immune response in the event of an eye infection later in life ${ }^{31,32}$.

In vitro bacterial resistance to antibiotics has been proven since $1940{ }^{34}$. Since then, resistance to antimicrobial agents increased around the globe, with multidrug-resistant microorganisms becoming more common. Bacteria develops resistance to antibiotics by mutations and exchange of genetic material at the cellular level ${ }^{35}$. The health field and the community put additional pressure in selecting resistant germs by extensive use of antibiotics in the hospitals and in the outpatient clinics, in the meat industry or by veterinarians, all these leading finally to the development and survival of resistant bacterial strains ${ }^{36}$.

\section{ARE OPHTHALMOLOGISTS INFLUENCING THE ANTIBIOTIC RESISTANCE PROFILES?}

At least two studies have shown that the use of antibiotic prophylaxis in intravitreal injections has led to a statistically significant increase in ocular colonization with resistant strains ${ }^{37}$.

In one study (Milder et al.) 80 eyes of 40 patients with exudative age-related macular degeneration who had previously received at least three injections in one eye were selected; the patients received an average of 7 injections (between 3-13) in the studied eye. For 4 days after the procedure some of the patients $(n=29)$ received a combination of a single drop of fluoroquinolone and polymyxin $\mathrm{B} /$ trimethoprim and the others $(\mathrm{n}=11)$ only fluoroquinolone $\mathrm{s}^{38-40}$. The fluoroquinolone resistance rate was almost double compared to the control group (63.6\% vs. $32.1 \%, \mathrm{P}=0.04)$. Moreover, of the eyes treated with fluoroquinolone 4 days after injection, the resistance was $87.5 \%(\mathrm{n}=8)$, compared to the untreated eye $-25 \%(\mathrm{P}=0.04){ }^{40}$. No differences were found in trimethoprim resistance.
In a prospective longitudinal randomized study 48 eyes were selected from 24 patients who underwent unilateral intravitreal injections, the second eye representing the control ${ }^{40}$. The patients were randomized to use ofloxacin, gatifloxacin, moxifloxacin or azithromycin (8 patients per group) after each injection. The injections were given every 4 weeks and the patients were instructed to use the antibiotic for 4 days after the procedure, 4 times a day for fluoroquinolones and 2 times a day for azithromycin. CoNS resistance prior to antibiotics was $57 \%$ for erythromycin, $65 \%$ for azithromycin, 34-39\% for moxifloxacin and gatifloxacin, $52-57 \%$ for ofloxacin and levofloxacin ${ }^{38}$. A total of 70 CoNS were isolated from the eyes control group; no significant increase in fluoroquinolone or macrolide resistance rates during the study period. Of the eyes treated with fluoroquinolones 48 cultures were positive for CoNS, with resistance to ofloxacin and levofloxacin of approximately $85 \%(\mathrm{P}=0.003)$, resistance to gatifloxacin of $67 \%(\mathrm{P}=0.009)$, to moxifloxacin $77 \%$ $(\mathrm{P}<0.001)$. A similar trend was recorded for azithromycin-treated eyes, with 94\% macrolide resistance ( $\mathrm{P}$ $=0.009)$ and low levels of fluoroquinolone resistance ${ }^{38}$.

Hsu et al. studied changes in conjunctival flora in a group of patients undergoing intravitreal injections who were not treated with post-procedural antibiotic, using only iodine-povidone antisepsis. The study concluded that there were no significant changes in ocular flora or resistance patterns ${ }^{38}$. All three studies suggest that the use of antibiotics could have a measurable and immediate influence on the developing resistant bacterial strains.

The World Health Organization, the United States Food and Drug Administration, and other large health organizations have developed surveillance programs that collect data from the United States and from countries of the rest of the world ${ }^{41}$.

Two such initiatives are of particular interest in the field of ophthalmology - Ocular Tracking Resistance in the U.S. Today (TRUST) and Antibiotic Resistance Monitoring in Ocular Microorganisms (ARMOR) ${ }^{42-}$ 44.

TRUST is a multicenter surveillance program in the United States started in 1996; isolates from more than 200 laboratories are sent to an independent central laboratory for in vitro susceptibility testing. A substudy was initiated in 2005 (Ocular TRUST1) that wants to collect data prospectively each year, as well as to retrospectively analyze samples from previous years. 
The TRUST study specifically analyzes 3 microorganisms: Staphylococcus aureus, Streptococcus pneumoniae, Haemophilus influenzae. S. aureus was subsequently divided into methicillin-sensitive (MSSA) or methicillin-resistant (MRSA) ${ }^{33}$.

The ARMOR study is a similar surveillance program developed specifically to surveille ocular pathogens in the United States. The initial results of the ARMOR study based on isolates collected from 34 institutions during 2009 were published in 2011 (ARMOR 2009), and data between 2009-2013 (ARMOR 2013) were published in 2017. The ARMOR study extends the data collected by TRUST studies by further analysis of Pseudomonas aeruginosa and coagulase-negative staphylococci (CoNS). The ARMOR 2013 study analyzed a total of 3237 isolates, representing the largest study of its kind performed (Table 2).

\section{DIFFICULTIES IN ASSESSING BACTERIAL RESISTANCE IN OPHTHALMOLOGY}

The studies that evaluated antibiotic resistance in ophthalmic practice have often faced the problem of the small number of cases. This is especially true for microorganisms isolated from endophthalmitis cases; the low disease incidence made the results obtained unlikely to be statistically significant ${ }^{43}$. Although the Ocular TRUST and ARMOR 2009 studies included a large number of prospectively harvested isolates, the trends of the resistance patterns were only published in ARMOR 2013 study.

Another limitation of the published studies is the different ways to detect susceptibility of bacteria to antibiotics. The determination of bacterial resistance

\begin{tabular}{|c|c|c|c|c|c|c|c|c|c|}
\hline Bacteria & & Penicillin & Azitromicin & Gatifloxacin & Moxifloxacin & Levofloxacin & Ofloxacin & Tobramicin & Ciprofloxacin \\
\hline $\begin{array}{l}\text { Streptococcus } \\
\text { penumoniae }\end{array}$ & $\begin{array}{l}\text { TRUST retrospectiv } \\
\text { TRUST prospectiv } \\
\text { ARMOR }\end{array}$ & $\begin{array}{l}34.1 \% \\
18.3 \% \\
31.8 \%\end{array}$ & $\begin{array}{l}33.4 \% \\
22.4 \% \\
34.8 \%\end{array}$ & $\begin{array}{l}0.3 \% \\
0 \% \\
0.4 \%\end{array}$ & $\begin{array}{l}0.1 \% \\
0 \% \\
0.3 \%\end{array}$ & $\begin{array}{l}0.1 \% \\
0 \% \\
0 \%\end{array}$ & $0.4 \%$ & $\begin{array}{l}95.1 \% \\
98 \%\end{array}$ & $\begin{array}{l}9.7 \% \\
10.2 \%\end{array}$ \\
\hline $\begin{array}{l}\text { MS Staphylococ- } \\
\text { cus aureus (MSSA) }\end{array}$ & $\begin{array}{l}\text { TRUST prospectiv } \\
\text { ARMOR }\end{array}$ & $90.2 \%$ & $\begin{array}{l}45.7 \% \\
42.8 \%\end{array}$ & $\begin{array}{l}18.9 \% \\
13.5 \%\end{array}$ & $\begin{array}{l}18.9 \% \\
12 \%\end{array}$ & $\begin{array}{l}18.9 \% \\
13.7 \%\end{array}$ & $14.1 \%$ & $\begin{array}{l}7.3 \% \\
4.1 \%\end{array}$ & $\begin{array}{l}20.1 \% \\
14.2 \%\end{array}$ \\
\hline $\begin{array}{c}\text { MR Staphylococcus } \\
\text { aureus (MRSA) }\end{array}$ & $\begin{array}{l}\text { TRUST prospectiv } \\
\text { ARMOR }\end{array}$ & $100 \%$ & $\begin{array}{l}93.9 \% \\
93.3 \%\end{array}$ & $\begin{array}{l}84.8 \% \\
75.1 \%\end{array}$ & $\begin{array}{l}84.8 \% \\
74 \%\end{array}$ & $\begin{array}{l}84.9 \% \\
75.9 \%\end{array}$ & $76.4 \%$ & $\begin{array}{l}63.6 \% \\
44.3 \%\end{array}$ & $\begin{array}{l}84.8 \% \\
77.3 \%\end{array}$ \\
\hline $\begin{array}{l}\text { MS coagulase- } \\
\text { negative } \\
\text { stafylococci }\end{array}$ & ARMOR & & $44.7 \%$ & $13.9 \%$ & $13.6 \%$ & $13.9 \%$ & $14.2 \%$ & $6.4 \%$ & $15 \%$ \\
\hline $\begin{array}{l}\text { MR coagulase- } \\
\text { negative } \\
\text { stafylococci }\end{array}$ & ARMOR & & $78.3 \%$ & $55.7 \%$ & $51.2 \%$ & $56.8 \%$ & $56.9 \%$ & $23.1 \%$ & \\
\hline H. influenzae & \begin{tabular}{|l} 
TRUST \\
retrospectiv
\end{tabular} & $100 \%$ & $0.3 \%$ & $0.3 \%$ & $0.3 \%$ & $0.3 \%$ & & $0 \%$ & \\
\hline P. aeruginosa & ARMOR & & & & & $6.9 \%$ & $10.1 \%$ & $3.1 \%$ & \\
\hline
\end{tabular}

Table 2. Intermediate and high-levels of resistance in TRUST and ARMOR studies. 
is based on the minimum inhibitory concentration (MIC), the lowest concentration of an antimicrobial agent that inhibits the growth of a particular microorganism. The MIC used in most studies are based on systemic drug administration, respectively the average concentrations reached by the antibiotic in the tissues ${ }^{42,43}$. Topical antibiotic administration, frequently used in ophthalmic practice, achieves longer antibiotic exposure over time compared to systemic administration $^{4,13,42,43}$. According to Ocular TRUST1, a study analyzing the pharmacokinetics of a $0.5 \%$ levofloxacin ophthalmic solution, the area under the curve (AUC) - an area of time exposure to the drug - over a period of 6 hours was more than double than the oral or intravenous dose of $750 \mathrm{mg}$ levofloxacin over a period of $24 \mathrm{~h}{ }^{43}$. Similar results were reported for azithromycin, with topical solutions of $0.5 \%, 1 \%$ and $1.5 \%$, resulting in an AUC 0-24 (measure of 24-hour drug exposure) between 108 and 362, two orders of magnitude more than administration of standard regimens of 3 or 5 days (AUC 0-24 at values of 2.58, 2.60 and 8.62) ${ }^{43,45}$.

Another problem in correlating laboratory data with clinical efficacy lies in the difficulty of obtaining data on the penetration of topical antibiotics into the deep structures of the eye and, consequently, their concentrations over time. Antibiotic penetration may be another factor influencing clinical success rates, although there are limited data on this topic. One study found that topically administered moxifloxacin and gatifloxacin penetrated the anterior chamber of the eye to a greater degree than ciprofloxacin, reaching much higher concentrations ${ }^{46}$.

Another aspect that makes it difficult to accurately assess resistance is the lack of a standardized framework for the study of ocular pathogens, as well as different interpretation criteria for susceptibility. Although some of the studies mentioned above used the thresholds set by CLSI, others used automated systems, and other studies reported the test method or the laboratory that performed the test but did not mention anything about the chosen threshold levels ${ }^{47}$. A potential weakness of Ocular TRUST1 or ARMOR studies is selection bias. The methodology of both studies is based on the analysis of samples from already cultured microorganisms. However, cultures in ophthalmology are quite rare, and although treatment guidelines for many of the eye infections claim that culture samples should be taken before antibiotic treatment is started, clinicians often begin empirical treatment and collect culture samples only if therapy fails ${ }^{18,48}$. In addition, crops are more likely to be grown if the severity of the infection is higher. Overall, this may alter the results and mask more severe and potentially more resistant infections. Finally, both studies focused strictly on microbial isolates from only certain bacterial species, thus omitting the spectrum of antibiotic resistance of other pathogenic bacteria.

\section{RESISTANCE PROFILE IN TRUST AND ARMOR STUDIES}

\section{Streptococcus pneumoniae}

A retrospective analysis of 760 positive samples for $S$. pneumoniae collected between 1999 and 2006 in the TRUST study shows a percentage of $34.1 \%$ penicillin resistance, with almost three quarters of the samples showing cross-resistance to azithromycin and trimethoprim $^{3}$. Data collected by the Ocular TRUST1 study between 2005 and 2006 identified 9 of the 49 (18.3\%) isolates of $S$. pneumoniae as being resistant to penicillin, all also resistant to trimethoprim, azithromycin and tobramycin ${ }^{43}$. Only one isolate of the 760 showed resistance to $3 \mathrm{rd}$ and 4 th generation fluoroquinolones (levofloxacin, moxifloxacin, gatifloxacin). Resistance to ciprofloxacin was $9.7 \%$. There were no statistically significant changes in S. pneumoniae susceptibility to fluoroquinolones during the 8 years of the study ${ }^{43}$.

ARMOR 2013 shows resistance to penicillin of $31.4 \%$, to azithromycin of $38.4 \%$ and a single fluoroquinolone resistant isolate, regardless of their generation ${ }^{43}$.

\section{Pseudomonas aeruginosa}

P. aeruginosa resistance rates were low against all antibiotics tested in ARMOR 2013. Except for polymyxin B, susceptibility was over $90 \%$.

\section{Haemophilus influenzae}

Of the $356 \mathrm{H}$. influenzae isolates collected retrospectively in Ocular TRUST1 (1999-2006), 37.4\% were b-lactamase-producing. However, all samples were susceptible to penicillin and all other antibiotics tested, except for a $14.3 \%$ resistance to trimethoprim. In the prospective section of the Ocular TRUST1 study, b-lactamase-producing isolates accounted for $44 \%$ of all samples (14 of 32). But this had no impact on antibiotic resistance.

The ARMOR study confirmed these results, isolated tested in $2009(n=73)$ and in the next 4 years 
$(n=284)$ being susceptible to all antibiotics tested, except for two of the samples with resistance to only one antibiotic each. Neither b-lactamase production nor trimethoprim sensitivity ${ }^{43}$ were tested.

\section{Coagulase-negative staphylococci (CoNS) and Staphy- lococcus aureus}

In the prospective part of Ocular TRUST1, 83.2\% of S. aureus isolates are methicillin-sensitive (MSSA). Of the MSSAs, most were sensitive to fluoroquinolones, with less than $20 \%$ resistance to any of the fluoroquinolones tested in contrast to the percentages of 75-85\% fluoroquinolone resistance for methicillin-resistant microorganisms (MRSA). The only antibiotic consistently active on both MSSA and MRSA was trimethoprim, with resistance being only $6.4 \%$ for MRSA and 2.4\% for MSSA ${ }^{42}$.

Data from the ARMOR 2009 study show that $39 \%$ of $S$. aureus are resistant to methicillin (MRSA), compared to the $16.8 \%$ of Ocular TRUST1 isolated in $2006{ }^{43}$. Similar to the results from Ocular TRUST1, isolated MRSA proved to be multidrug-resistant, with $79.5 \%$ resistance to ciprofloxacin, $65.4 \%$ to moxifloxacin and $52.6 \%$ to tobramycin. Although fluoroquinolone resistance between the two studies did not increase, doubling the incidence of MRSA between samples of $S$. aureus may mean that eye infections are now much more likely to be caused by a methicillin-resistant, and possibly even multidrug-resistant, microbe. In ARMOR 2009, $11.5 \%$ of $S$. aureus isolates were resistant to five different classes of antibiotics. In ARMOR 2013, 86.8\% of MRSA and 77.3\% of methicillin-resistant CoNS were resistant to three or more classes of antibiotics.

In ARMOR 2013, of the CoNS isolates, the vast majority (75.9\%) were represented by Staphilococcus epidermidis, illustrating perhaps how often this species is part of the commensal flora ${ }^{42,43}$. The resistance rates in the ARMOR 2013 study show that the resistance profile of CoNS follows a trend similar to that of $S$. aures, with $49.7 \%$ resistance to methicillin (compared to $42.2 \%$ for $S$. aureus), $34.4 \%$ to ciprofloxacin $(39.8 \%$ for $S$ aureus) and $61.3 \%$ for azithromycin $(63.6 \%$ for $S$. aureus). Perhaps surprisingly, there was no statistically significant increase in CoNS or $S$. aureus resistance during the 5 years of surveillance in the 2013 ARMOR study.

\section{PREVENTION OF MICROBIAL DRUG- RESISTANCE IN OPHTHALMOLOGY}

\section{Avoiding subtherapeutic dosage}

A key element in prescribing antibiotics is their use in the right doses and for an appropriate duration. Using a too low dose - subtherapeutic dosing - can accelerate the development of resistance. Microbes are exposed to antibiotics without being killed, allowing them to develop resistance, multiply and spread. Similarly, they may develop resistance if the duration of treatment is too short.

Incorrect dosages are surprisingly common, especially in children, as many of the drugs are not available in pediatric doses. A possible explanation for this practice of suboptimal dosing of antibiotics could be the absence of recent studies related to their pharmacokinetics and pharmacodynamics. Many studies related to the pharmacokinetics and pharmacodynamics of antibiotics were developed in the years 1950-1960, when these antibiotics were first discovered. Currently, with the improved techniques and protocols used for this type of study, these antibiotics should be re-evaluated to ensure that they are used in the most effective way possible. Many of the antibiotics used in ophthalmology have topical or intracameral administration, so the results of studies related to their systemic administration are not applicable.

\section{Using the right antibiotic}

In an ideal world, prescribing an antibiotic would be done only after identifying the pathogen and its resistance profile, in order to choose the most appropriate antimicrobial treatment option. But in current medical practice this is not always possible, so antibiotics are often prescribed empirically. One of the major problems of the conventional method of culturing biological products on culture media which takes relatively long until the pathogen is identified and its sensitivity tested (at least 24-48h) ${ }^{49}$. Under these circumstances the ophthalmologist already started the treatment, empirically, based on the clinical examination of the patient.

To solve this problem, a series of rapid diagnostic tests have been developed. These include Polymerase Chain Reaction (PCR) and Peptide Nucleic Acid Fluorescence In Situ Hybridization (PNA-FISH). These tests work by identifying known resistances using species-specific genomic sequences. PCR amplifies the 
searched sequence by making it detectable by other methods such as electrophoresis, while PNA-FISH uses fluorescence for detection. The results of these tests are available in 45 minutes, up to 6 hours ${ }^{50}$.

Another method for rapid susceptibility testing is Bacterial Cytological Profiling (BCP). The cultured pathogens are exposed to an antimicrobial, and the response in terms of cell and nucleus size is evaluated by fluorescence microscopy, with specific changes indicating susceptibility or resistance to that molecule. It is important to know that none of these methods are developed minding the ophthalmological practice but to identify systemic infections, so they must be adapted for use in ophthalmology. In the future, these innovations will be able to help ophthalmologists choose the right antibiotic, being confident in its therapeutic effect, while keeping certain antibiotics as a reserve.

\section{Using antibiotics only when they bring an obvious benefit}

A key message in any program that aim the responsible use of antibiotics is the importance of using them only when really needed ${ }^{51}$. Antimicrobial prophylaxis in intravitreal injections is only one example for which studies have shown that alternative methods of infection control are at least as effective ${ }^{52}$. An additional benefit of not using antibiotic prophylaxis in intravitreal injections is economic, with estimated savings of $\$$ 300 million in the US, compared to the use of antimicrobials for each procedure ${ }^{6}$.
A second area in which a large-scale change in medical practice would be possible is the use of topical antibiotics before cataract surgery. A literature review concluded that despite the widespread use of this practice, the evidence to support it is not convincing ${ }^{53}$.

Finally, antibiotics are sometimes misused in the treatment of viral or allergic conjunctivitis ${ }^{54}$. Studies show that up to $80 \%$ of conjunctivitis are of viral origin, self-limiting and do not require antibiotic treatment and ${ }^{53}$. All these problems have been identified in the past, the American Academy of Ophthalmology designating the use of antibiotics for intravitreal injections and viral conjunctivitis as two of the top 5 unnecessary interventions in ophthalmology 55 .

\section{ALTERNATIVES TO ANTIBIOTICS}

One of the possible alternatives already used in ophthalmology is the effective use of antiseptics in the case of intravitreal injections. In recent years, a large-scale study has demonstrated the safety of 5\% iodine-povidone solutions in preventing endophthalmitis associated with intravitreal injections ${ }^{56}$. A recent questionnaire conducted by American retinal specialists shows that $89 \%$ of them do not use any antibiotics in intravitreal injections, while another $5 \%$ use antibiotics only for selected patients. These results reflect that the non-use of antibiotics is possible even today. It is hoped that future reports from the US that show good results without the use of antibiotics will encourage other ophthalmol-

\begin{tabular}{|c|c|c|c|}
\hline & & Clorhexidine & Povidone-iodine $10 \%$ \\
\hline $\begin{array}{c}\text { Gram-positive } \\
\text { bacteria }\end{array}$ & $\begin{array}{l}\text { Activity } \\
\text { Spectrum }\end{array}$ & $\begin{array}{l}\text { High } \\
\text { Large }\end{array}$ & $\begin{array}{l}\text { High } \\
\text { Large }\end{array}$ \\
\hline $\begin{array}{c}\text { Gram-negative } \\
\text { bacteria }\end{array}$ & $\begin{array}{l}\text { Activity } \\
\text { Spectrum }\end{array}$ & $\begin{array}{c}\text { High } \\
\text { Incomplete }\end{array}$ & $\begin{array}{l}\text { High } \\
\text { Large }\end{array}$ \\
\hline Fungi & $\begin{array}{c}\text { Activity } \\
\text { Spectrum }\end{array}$ & $\begin{array}{c}\text { Medium } \\
\text { Incomplete }\end{array}$ & $\begin{array}{l}\text { High } \\
\text { Large }\end{array}$ \\
\hline Viruses & $\begin{array}{l}\text { Activity } \\
\text { Spectrum }\end{array}$ & $\begin{array}{c}\text { Low } \\
\text { Incomplete }\end{array}$ & $\begin{array}{l}\text { Medium } \\
\text { Large }\end{array}$ \\
\hline Actinobacteria & Activity & No activity & Medium \\
\hline Spores & Activity & No activity & Medium \\
\hline
\end{tabular}

Table 3. Spectrum of antimicrobial activity of iodine-povidone and chlorhexidine (taken from Grzybowski et al.33) 
ogists to limit the use of topical antibiotics, reducing the rate of antimicrobial resistance.

Antiseptics have become an important element in preventing postoperative endophthalmitis. Iodine-povidone and chlorhexidine are two major antiseptics used in ophthalmology. Iodine-povidone solutions work by releasing free iodine that penetrates the microbial membrane, causing oxidation of intracytoplasmic proteins and consequent cell death ${ }^{57}$. Chlorhexidine is a much larger molecule that cannot cross the cell wall. Depending on the concentration, it can exert a bacteriostatic effect, destroying cell membranes, or bactericidal by coagulating and precipitating intracellular components. Although both antiseptics have good activity on a wide range of gram-positive bacteria, iodine-povidone has a broad spectrum in other microorganisms. The activity spectrum of the two antiseptics is compared in Table 3.

Although both antiseptics may cause hypersensitivity reactions, no anaphylactic-type reactions have been reported after topical use of iodine-povidone ${ }^{58}$. The allergic profile of iodine-povidone is considered excellent; skin reactions are also very rare, being irritative rather than allergic ${ }^{59}$. Reactions to chlorhexidine are more frequent - contact dermatitis, urticaria and anaphylactic reactions being described.

Unfortunately, resistance phenomena are not limited to antibiotics. Resistance to chlorhexidine has been described, especially in MRSA or other staphylococcal infections, and several responsible genes have been identified ${ }^{60}$. There are apparently no data on iodine-povidone resistance. One study showed that $1.25 \%$ iodine-povidone solution is an effective alternative therapy to antibiotics in bacterial keratitis, suggesting that its use as an antiseptic in ophthalmology could extend beyond prevention ${ }^{61}$.

\section{CONCLUSIONS}

The ocular surface hosts various microorganisms. We have, based on current information, a good understanding of eye microbiome. However, much remains to be learned about resistance and pathogenicity of the ocular flora in order to effectively prevent resistance in ophthalmology.

Effective antimicrobials are needed in ophthalmology, both curatively and for prevention. However, it is critical to determine which antibiotics should be used in various situations and where alternatives to antibi- otics are appropriate. Intravitreal injections are just one example where improper use of antibiotics can lead to serious consequences.

When antibiotics are needed, they should be used in accordance with the guidelines to obtain high concentrations in the target tissues and a sufficient duration of antimicrobial effect, necessary to prevent resistance. Repeated short-term exposure to topical antibiotics, as with intravitreal injections for chronic retinal disease, can quickly lead to the development of resistance in the ocular microbiome. This was demonstrated by the high rates of resistance to moxifloxacin and gatifloxacin (up to $70 \%$ ) in patients undergoing intravitreal injection therapy receiving antibiotic prophylaxis, in just one year of serial injections ${ }^{62}$.

It is equally important for clinicians to be aware that the designation of a microorganism as resistant is based on systemic antibiotic administration and systemic infection. Concentrations obtained by topical antibiotic administration are often higher and may still be effective.

Unfortunately for ophthalmologists, most research is based on systemic infections and some of these will never be validated for ophthalmic use.

The situation is different for antiseptics. Iodine-povidone and chlorhexidine are already used in practice, and their use could be expanded to replace antibiotics in certain procedures. Most importantly, both antiseptics have the advantage of acting through a non-selective mechanism (thus preventing the development of resistance) and have a low cost.

\section{Compliance with ethics requirements:}

The authors declare no conflict of interest regarding this article. The authors declare that all the procedures and experiments of this study respect the ethical standards in the Helsinki Declaration of 1975, as revised in 2008(5), as well as the national law. Informed consent was obtained from all the patients included in the study. 


\section{References}

1. Mollan SP, Gao A, Lockwood A, Durrani OM, Butler L. Postcataract endophthalmitis: Incidence and microbial isolates in a United Kingdom region from 1996 through 2004. J Cataract Refract Surg. 2007;33(2):265-8. doi: 10.1016/j.jcrs.2006.10.022.

2. Rose P. Management strategies for acute infective conjunctivitis in primary care: a systematic review. Expert Opin Pharmacother. 2007;8(12):1903-1921.

3. Bertino JS. Impact of antibiotic resistance in the management of ocular infections: The role of current and future antibiotics. Clin Ophthalmol. 2009;3(1):507-521.

4. Ta CN, Chang RT, Singh K, et al. Antibiotic resistance patterns of ocular bacterial flora: A prospective study of patients undergoing anterior segment surgery. Ophthalmology. 2003;110(10):194651. doi: 10.1016/s0161-6420(03)00735-8.

5. Armstrong RA. The microbiology of the eye. Ophthalmic Physiol Opt. 2000;20(6):429-41

6. Taban M, Behrens A, Newcomb RL, et al. Acute endophthalmitis following cataract surgery: A systematic review of the literature. Arch Ophthalmol. 2005; 123(5):613-20. doi: 10.1001/archopht.123.5.613.

7. Schwartz SG, Grzybowski A, Flynn HW. Antibiotic prophylaxis: Different practice patterns within and outside the United States. Clin Ophthalmol. 2016;10:251-6. doi: 10.2147/OPTH.S100429.

8. Liesegang TJ. Use of antimicrobials to prevent postoperative infection in patients with cataracts. Curr Opin Ophthalmol. 2001;12(1):68-74. doi:10.1097/00055735-200102000-00012.

9. Chang DF, Braga-Mele R, Henderson BA, Mamalis N, Vasavada A. Antibiotic prophylaxis of postoperative endophthalmitis after cataract surgery: Results of the 2014 ASCRS member survey. J Cataract Refract Surg. 2015;41(6):1300-5. doi: 10.1016/j. jcrs.2015.01.014.

10. Cao H, Zhang L, Li L, Lo SK. Risk Factors for Acute Endophthalmitis following Cataract Surgery: A Systematic Review and Meta-Analysis. PLoS One. 2013;26;8(8):e71731. doi: 10.1371/journal.pone.0071731

11. Graham JE, Moore JE, Jiru X, et al. Ocular pathogen or commensal: A PCR-based study of surface bacterial flora in normal and dry eyes. Investig Ophthalmol Vis Sci. 2007;48(12):5616-23. doi: 10.1167/iovs.07-0588

12. De Kaspar HM, Kreidl KO, Singh K, Ta CN. Comparison of preoperative conjunctival bacterial flora in patients undergoing glaucoma or cataract surgery. J Glaucoma. 2004; 13(6):507-9. doi: 10.1097/01.ijg.0000137872.19942.cf.

13. Suto $C$, Morinaga M, Yagi T, Tsuji $C$, Toshida H. Conjunctival sac bacterial flora isolated prior to cataract surgery. Infect Drug Resist. 2012;5:37-41. doi: 10.2147/IDR.S27937.

14. Smith $\mathrm{CH}$. Bacteriology of the healthy conjunctiva. Br J Ophthalmol. 1954;38(12):719-26. doi: 10.1136/bjo.38.12.719.

15. Perkins RE, Kundsin RB, Pratt M V. Bacteriology of normal and infected conjunctiva. J Clin Microbiol. 1975;(2):147-9. doi: 10.1128/ JCM.1.2.147-149.1975

16. Capriotti JA, Pelletier JS, Shah M, Caivano DM, Ritterband DC Normal ocular flora in healthy eyes from a rural population in Sierra Leone. Int Ophthalmol. 2009;29(2):81-4. doi: 10.1007/ s10792-008-9196-4.

17. Park SH, Lim JA, Choi JS, Kim KA, Joo CK. The resistance patterns of normal ocular bacterial flora to 4 fluoroquinolone antibiotics. Cornea. 2009;28(1):68-72. doi: 10.1097/IC0.0b013e318182259b.

18. Olson R, Donnenfeld E, Bucci FA, et al. Methicillin resistance of Staphylococcus species among health care and nonhealth care workers undergoing cataract surgery. Clin Ophthalmol. 2010;10:4:1505-14. doi: 10.2147/OPTH.S14333.
19. Honda R, Toshida H, Suto C, et al. Effect of long-term treatment with eyedrops for glaucoma on conjunctival bacterial flora. Infect Drug Resist. 2011;4:191-6. doi: 10.2147/IDR.S24250. Epub 2011 Oct 20.

20. Mshangila B, Paddy M, Kajumbula $H$, Ateenyi-Agaba $C$, Kahwa $B$, Seni J. External ocular surface bacterial isolates and their antimicrobial susceptibility patterns among pre-operative cataract patients at Mulago National Hospital in Kampala, Uganda. BMC Ophthalmol. 2013;13:71. doi: 10.1186/1471-2415-13-71.

21. Willcox MDP. Characterization of the normal microbiota of the ocular surface. Exp Eye Res. 2013;117:99-105. doi: 10.1016/j. exer.2013.06.003

22. Albrich WC, Harbarth S. Healthcare workers - Source, vector or victim of MRSA? Int J Antimicrob Agents. 2007;8(5):289-301. doi: 10.1016/S1473-3099(08)70097-5.

23. Hsu HY, Lind JT, Miller D, Tseng L. Assessment of risk factors for oxacillin-resistant ocular flora in eyes having cataract surgery. J Cataract Refract Surg. 2015;41(2):387-92. doi: 10.1016/j. jcrs.2014.05.050.

24. Adam M, Balcı M, Bayhan HA, İnkaya AÇ, Uyar M, Gürdal C. Conjunctival flora in diabetic and nondiabetic individuals. Turk Oftalmoloiji Derg. 2015;45(5):193-196. doi: 10.4274/tjo.33230. Epub 2015 Oct 5

25. Moreno NP, Moreno RD, Sousa LB. Aerobic bacterial microbiota of the conjunctiva in diabetic patients with normal and altered glycated hemoglobin levels in two regions in Brazil. Arq Bras Oftalmol. 2014;77(6):351-4. doi: 10.5935/0004-2749.20140

26. Shanmuganathan VA, Armstrong M, Buller A, Tullo AB. External ocular infections due to methicillin-resistant Staphylococcus aureus (MRSA). Eye. 2005;19(3):284-91. doi: 10.1038/sj. eye.6701465.

27. Rubio EF. Climatic influence on conjunctival bacteria of patients undergoing cataract surgery. Eye. 2004;18(8):778-84. doi: 10.1038/sj.eye.6701352.

28. Gunduz G, Gunduz A, Polat N, Cumurcu BE, Yakupogulları Y. The Effect of Chronic Alcoholism on the Conjunctival Flora. Curr Eye Res. 2016;41(6):734-9. doi: 10.3109/02713683.2015.1056805.

29. Gündüz $A$, Gündüz $A$, Cumurcu $T$, Seyrek $A$. Conjunctival flora in Behçet patients. Can J Ophthalmol. 2008;43(4):476-9. doi: 10.3129/i08-089.

30. Gritz DC, Scott TJ, Sedó SF, Cevallos AV, Margolis TP, Whitcher JP. Ocular flora of patients with AIDS compared with those of HIV-negative patients. Cornea. 1997;16(4):400-5.

31. Balikoglu-Yilmaz M, Sen E, Sevket O, Polat Y, Karabulut A, Uysal O. Comparison of aerobic conjunctival bacterial flora in pregnant, reproductive-aged and postmenopausal women. Int J Ophthalmol. 2012;5(6):731-6. doi: 10.3980/j.issn.2222-3959.2012.06.15.

32. Zaidi T, Cywes-Bentley C, Lu R, Priebe GP, Pier GB. Microbiota-driven immune cellular maturation is essential for Antibody-mediated adaptive immunity to Staphylococcus aureus Infection in the eye. Infect Immun. 2014;82(8):3483-91. doi: 10.1128/IAl.01951-14.

33. Grzybowski A, Brona P, Kim SJ. Microbial flora and resistance in ophthalmology: a review. Graefe's Arch Clin Exp Ophthalmol. 2017;255(5):851-862.

34. Kugadas A, Gadjeva M. Impact of Microbiome on Ocular Health Ocul Surf. 2016;14(3):342-9. doi: 10.1016/j.jtos.2016.04.004.

35. Demerec M. Origin of Bacterial Resistance to Antibiotics. J Bacteriol. 1948;56(1):63-74. doi: 10.1128/JB.56.1.63-74.

36. Tenover FC. Development and Spread of Bacterial Resistance to Antimicrobial Agents: An Overview. Clin Infect Dis. 2001;33 Suppl 3:S108-15. doi: 10.1086/321834 
37. Mio de Kaspar H, Hoepfner AS, Engelbert M, et al. Antibiotic resistance pattern and visual outcome in experimentally-induced Staphylococcus epidermidis endophthalmitis in a rabbit model. Ophthalmology. 2001;108(3):470-8. doi: 10.1016/s01616420(00)00545-5.

38. Kim SJ, Toma HS. Ophthalmic antibiotics and antimicrobial resistance: A randomized, controlled study of patients undergoing intravitreal injections. Ophthalmology. 2011;118(7):1358-63. doi: 10.1016/j.ophtha.2010.12.014.

39. Dave SB, Toma HS, Kim SJ. Changes in ocular flora in eyes exposed to ophthalmic antibiotics. Ophthalmology. 2013;120(5):937-41. doi:10.1016/j.ophtha.2012.11.005

40. Milder E, Vander J, Shah C, Garg S. Changes in antibiotic resistance patterns of conjunctival flora due to repeated use of topical antibiotics after intravitreal injection. Ophthalmology. 2012;119(7):1420-4. doi: 10.1016/j.ophtha.2012.01.016.

41. Hsu J, Gerstenblith AT, Garg SJ, Vander JF. Conjunctival flora antibiotic resistance patterns after serial intravitreal injections without postinjection topical antibiotics. Am J Ophthalmol. 2014;157(3):514-8.e1. doi: 10.1016/j.ajo.2013.10.003.

42. Haas W, Pillar CM, Torres M, Morris TW, Sahm DF. Monitoring antibiotic resistance in ocular microorganisms: Results from the Antibiotic Resistance Monitoring in Ocular Microorganisms (ARMOR) 2009 surveillance study. Am J Ophthalmol. 2011;152(4):567-574.e3. doi: 10.1016/j.ajo.2011.03.010.

43. Asbell PA, Colby KA, Deng S, et al. Ocular TRUST: Nationwide Antimicrobial Susceptibility Patterns in Ocular Isolates. Am J Ophthalmol. 2008;145(6):951-958. doi: 10.1016/j.ajo.2008.01.025.

44. Dar OA, Hasan R, Schlundt J, et al. Exploring the evidence base for national and regional policy interventions to combat resistance. Lancet. 2016;387(10015):285-95. doi: 10.1016/S01406736(15)00520-6

45. Raizman MB, Rubin JM, Graves AL, Rinehart M. Tear concentrations of levofloxacin following topical administration of a single dose of $0.5 \%$ Levofloxacin ophthalmic solution in healthy volunteers. Clin Ther. 2002;24(9):1439-50. doi: 10.1016/s01492918(02)80047-9.

46. Chiambaretta F, Garraffo R, Elena PP, et al. Tear concentrations of azithromycin following topical administration of a single dose of azithromycin 0.5\%, $1.0 \%$, and $1.5 \%$ eyedrops (T1225) in healthy volunteers. Eur J Ophthalmol. 2008;18(1):13-20. doi: 10.1177/112067210801800103

47. Benz MS, Scott IU, Flynn HW, Unonius N, Miller D. Endophthalmitis isolates and antibiotic sensitivities: A 6-year review of culture-proven cases. Am J Ophthalmol. 2004;137(1):38-42. doi: 10.1016/s0002-9394(03)00896-1

48. Ramakrishnan R, Bharathi MJ, Shivkumar C, et al. Microbiological profile of culture-proven cases of exogenous and endogenous endophthalmitis: A 10-year retrospective study. Eye. 2009;23(4):945-56. doi: 10.1038/eye.2008.197.

49. Lestner JM, Versporten A, Doerholt K, et al. Systemic antifungal prescribing in neonates and children: Outcomes from the antibiotic resistance and prescribing in european children (arpec) study. Antimicrob Agents Chemother. 2015;59(2):782-9.doi: 10.1128/AAC.04109-14.

50. Goff DA, Jankowski C, Tenover FC. Using rapid diagnostic tests to optimize antimicrobial selection in antimicrobial stewardship programs. Pharmacotherapy. 2012;32(8):677-87. doi: 10.1002/j.1875-9114.2012.01137.x.

51. Quach DT, Sakoulas G, Nizet V, et al. Bacterial Cytological Profiling (BCP) as a Rapid and Accurate Antimicrobial Susceptibility Testing Method for Staphylococcus aureus. EBioMedicine. 2016;4:95-103. doi: 10.1016/j.ebiom.2016.01.020.
52. Pollack LA, Srinivasan A. Core elements of hospital antibiotic stewardship programs from the Centers for Disease Control and Prevention. Clin Infect Dis. 2014;59 Suppl 3(Suppl 3):S97100. doi: 10.1093/cid/ciu542.

53. Parke DW, Coleman AL, et al. Choosing wisely: Five ideas that physicians and patients can discuss. Ophthalmology. 2013;120(3):443-444. doi: 10.1016/j.ophtha.2013.01.017.

54. Grzybowski A, Kuklo P, Pieczynski J, Beiko G. A review of preoperative manoeuvres for prophylaxis of endophthalmitis in intraocular surgery: Topical application of antibiotics, disinfectants, or both? Curr Opin Ophthalmol. 2016;27(6):486-492. doi: 10.1097/ ICU.0000000000000316.

55. Azari AA, Barney NP. Conjunctivitis: A systematic review of diagnosis and treatment. JAMA - J Am Med Assoc. 2013;310(16):17219. doi: 10.1001/jama.2013.280318.

56. Czaplewski L, Bax R, Clokie M, et al. Alternatives to antibiotics-a pipeline portfolio review. Lancet Infect Dis. 2016;16(2):23951. doi: 10.1016/S1473-3099(15)00466-1.

57. Dossarps D, Bron AM, Koehrer P, et al. Endophthalmitis after intravitreal injections: Incidence, presentation, management, and visual outcome. Am J Ophthalmol. 2015;160(1):17-25.e1. doi: 10.1016/j.ajo.2015.04.013

58. Lachapelle JM, Castel O, Casado AF, et al. Antiseptics in the era of bacterial resistance: A focus on povidone iodine. Clin Pract. 2013.

59. Merani R, Hunyor AP. Endophthalmitis following intravitreal anti-vascular endothelial growth factor (VEGF) injection: A comprehensive review. Int J Retin Vitr. 2015;1:9. doi: 10.1186/s40942015-0010-y.

60. Lachapelle JM. A comparison of the irritant and allergenic properties of antiseptics. Eur J Dermatology. 2014;24(1):3-9. doi: 10.1684/ejd.2013.2198.

61. Horner C, Mawer D, Wilcox M. Reduced susceptibility to chlorhexidine in staphylococci: Is it increasing and does it matter? J Antimicrob Chemother. 2012;67(11):2547-59. doi: 10.1093/jac/ dks284.

62. Isenberg SJ, Apt L, Valenton M, et al. Prospective, Randomized Clinical Trial of Povidone-Iodine 1.25\% Solution Versus Topical Antibiotics for Treatment of Bacterial Keratitis. Am J Ophthalmol. 2017;176:244-253. doi: 10.1016/j.ajo.2016.10.004. 